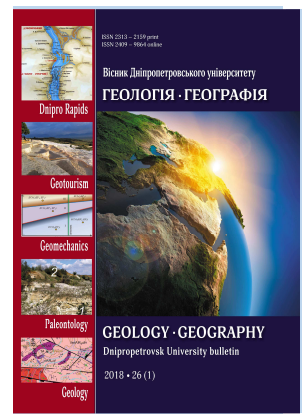

\section{Geology • Geography \\ Dnipro university bulletin}

ISSN 2313-2159 (print)

ISSN 2409-9864(online)

Dniprop. Univer.bulletin. Geology, geography., 26(1), 17-25.

Journal home page: geology-dnu-dp.ua

\title{
Морфологічні різновиди гематиту та їх перерозподіл по продуктах збагачення відсіву дро- бильно-сортувальних фабрик шахт Криворізького басейну
}

\author{
О. С. Демченко, В. Д. Євтєхов, А. В. Свтєхова
}

Криворізький начіональний університет, 37, вул. Пушкіна, м. Кривий Ріг, 50002, Украӥна E-mail: o.s.demchenko121@gmail.com; evtekhov@gmail.com; eva.anna23@gmail.com

\section{Received 25.01.2018 \\ Received in revised form $\quad 05.02 .2018$ Accepted 05.03.2018}

Анотація. Наведено результати вивчення петрографічного та мінерального складу відсіву дробильно-сортувальних фабрик шахт Криворізького басейну. Головні петрографічні компоненти відсіву - рядові і збагачені гематитові кварцити, багаті гематитові руди; другорядні - малорудні та безрудні кварцити, різного складу сланці, граніти, амфіболіти, жильний кварц. За даними мінералогічних досліджень, відсів має практично бімінеральний (гематит + кварц) склад. Детально досліджено особливості головного рудотвірного мінералу відсіву - гематиту. Виявлено характер перерозподілу його різних морфологічних відмін по різних продуктах рудопідготовки та збагачення. Показано, що емульсійний гематит нерудних прошарків гематитових кварцитів і дисперсний гематит «краскових» руд і малорудних гематитових кварцитів потрапляють, головним чином, до відходів збагачення. Спекулярит і мартит практично повністю потрапляють до концентрату. Наголошується на необхідності врахування одержаних результатів для мінералогічного обгрунтування оптимальної технології повторного збагачення відсіву з метою одержання високоякісного залізорудного концентрату.

Ключові слова: залізисто-кремниста формачія, Криворізький басейн, багаті залізні руди, відходи збагачення, відсів ДСФ, повторне збагачення, гематитовий концентрат

\section{Morphological varieties of hematite and their redistribution between the products of beneficia- tion of screenings from crushing and screening plants of Kryvy Rih basin mines}

\author{
O.S. Demchenko, V.D. Evtekhov, A.V. Evtekhova \\ Kryvyi Rih National University, 37, Pushkin str., Kryvyi Rih, 50002, Ukraine. \\ E-mail: o.s.demchenko121@gmail.com; evtekhov@gmail.com;eva.anna23@gmail.com
}

Abstract. The deposits of high-grade ores of the Kryvyi Rih basin are developed by seven mines and two open pits. Insufficient quality of extracted ore mass requires its beneficiation at the crushing and screening plants operating at each mine. Utilizing three-stage crushing and three-stage screening methods sinter ore having iron content of 57-61 mass \% (fine-grained (less than 20 mm) beneficiation product) is produced. The beneficiation waste is coarse-grained $(20-100 \mathrm{~mm})$ screening with an average iron content of 43 mass \%. The authors studied the possibility of using this material as a secondary raw material for the production high-quality iron ore concentrate. According to the results of petrographic studies, it mainly consists of particles of hematite quartzites with an admixture of high-grade hematite ores, low-iron and iron-free rocks. The screenings have two-component mineral composition - hematite + quartz with insignificant admixture of kaolinite, calcite, aragonite, dolomite, pyrite, marcasite, millstone, relic silicates (chlorite, biotite, cummingtonite). Hematite, being the main ore mineral, is represented by three morphological varieties such as martite, micaceous hematite and dispersed hematite. The hematite redistribution between ore-preparation products (crushing, grinding to particle size of less than $0.1 \mathrm{~mm}$ ) and screenings beneficiation was studied. Martite, which is a product of the hypergenic replacement of primary magnetite, represents a fine-porous differentiated aggregate, very small, multidirectional scaly crystals of hematite. Because of this, martite is subject to overgrinding in the ore preparation. The method of gravitational separation, which was used by the authors for beneficiation, allows most of the martite (particle size more than $0.02 \mathrm{~mm}$ ) to get in the concentrate; and overgrinded martite (less than $0.02 \mathrm{~mm}$ ) gets in beneficiation waste. In the process of grinding coarse-grained micaceous hematite (specularite) is effectively released and, when beneficiated, it gets in the concentrate. Thin-scaly aggregates of dispersed hematite are crushed to a particle size less than $0.01 \mathrm{~mm}$ and almost completely go to beneficiation wastes. Besides released particles of hematite and quartz, intergrown peaces having different proportions of these minerals are also formed in the course of grinding. During beneficiation process, high-grade aggregates with a hematite content more than $75 \%$ get in concentrates, the ones having the lower grade get into wastes. The different behavior of hematite of three morphological varieties in the course of ore preparation and beneficiation must be taken into account when developing an optimal technological scheme for the production of high-quality (67-69 mass.\% of iron) hematite concentrate. 
Key words: banded iron formation, Kryvyi Rih basin, rich iron ore, waste enrichment, screening of CSP, re-enrichment, hematite concentrate

Вступ. Поклади багатих залізних руд Криворізького басейну наразі розробляються сімома шахтами і двома невеликої потужності кар'єрами (рис. 1). До технологічної схеми кожної шахти входять дробильно-сортувальні фабрики (ДСФ). Їх завдання полягає у підвищенні вмісту заліза в складі видобутої з надр рудної маси 3 метою доведення цього показника до значень, які забезпечують конкурентоспроможність товарної агломераційної руди на світовому ринку - загальний вміст заліза 60-62 мас.\%. Відходом збагачення є крупнозернистий (20-100 мм) відсів ДСФ із вмістом заліза від 39 до 46, середній показник 43 мас.\%. Він розглядається як сировина для повторного збагачення $з$ метою виробництва високоякісного (залізорудного) концентрату із вмістом заліза 67-69 мас.\%. Для забезпечення ефективної технології збагачення необхідне детальне вивчення мінерального, хімічного складу відсіву, перерозподілу продуктотвірних та другорядних мінералів по продуктах його повторного збагачення.

Мета роботи - визначення мінерального складу відсіву діючих ДСФ Криворізького басейну та встановлення закономірностей перерозподілу головного мінералу відсіву - гематиту - між концентратом і відходами повторного збагачення.

Вихідний матеріал і методика досліджень. За вихідний використано матеріал 21 проби крупнозернистого відсіву ДСФ семи шахт Криворізького басейну. Проби відбирались протягом 2014-17 pр. - по три рядові проби відсіву масою 1000 кг зі складів ДСФ кожної шахти. Маса рядових проб визначалась за формулою $Q=k d^{2}$, де $Q$ - маса проби; $d$ - максимальний розмір частинок у складі матеріалу (100 мм); $k$ - емпірично визначений коефіцієнт, значення якого для залізорудної сировини становить 0,1 . Для більшого представництва відбір рядових проб кожної ДСФ виконувався з інтервалом один місяць. Матеріал трьох рядових проб кожної шахти був скомпонований в одну об'єднану пробу масою 3000 кг. Загальна маса відібраного матеріалу становила 21000 кг. Із матеріалу кожної з семи об'єднаних проб стандартним методом були відібрані наважки масою 50 кг для рудорозбирання, масою до 10 кг для виготовлення прозорих і полірованих шліфів, масою 300 кг для виконання хімічних аналізів і проведення попередніх технологічних експериментів. Матеріал, що залишився, був зарезервований для компонування генеральної проби, матеріал якої в подальшому буде використаний для узагальнювальних напівпромислових мінералого-технологічних досліджень.
У цій статті викладено результати вивчення петрографічного складу відсіву за даними рудорозбирання, його мінерального складу та особливостей перерозподілу гематиту по продуктах, одержаних у процесі проведення попередніх технологічних експериментів,- за даними мікроскопічних досліджень.

Визначення кількісних співвідношень основних мінеральних різновидів руд і гірських порід у складі відсіву виконувалось методом макро(частинки розміром від 100 до 5 мм) та мікроскопічного (менше 5 мм) рудорозбирання. Останне проводилось iз використанням бінокулярного (частинки розміром від 0,1 до 5 мм) і петрографічного (менше 0,1 мм) мікроскопів (Demchenko, Evtekhov 2015).

Попередні мінералого-технологічні дослідження були виконані для представницьких наважок, відібраних із матеріалу кожної об'єднаної проби відсіву ДСФ. Матеріал наважок подробили до крупності частинок $-20+0$ мм. Продукти дроблення 3 використанням лабораторного кульового млина 40-МЛ були подрібнені до крупності частинок $-0,1+0$ мм. При цьому бралось до уваги, що максимальний розмір частинок у продуктах подрібнення відповідає максимальному розміру частинок кварцу, кристали якого більш міцні порівняно 3 тонкопористими агрегатами мартиту. Внаслідок цього частинки мартиту, розмір яких у рудах і гематитових кварцитах відсіву в середньому становить близько 0,07 мм гарантовано розкриті в складі продуктів подрібнення.

Із матеріалу кожного мінерального різновиду багатих руд, рядових гематитових кварцитів та домішкових гірських порід, які входять до складу відсіву, а також з одержаних продуктів подрібнення, продуктів їх гравітаційного збагачення були виготовлені близько 200 прозорих i полірованих шліфів. Застосовуючи стандартні методи проводили ідентифікацію рудо- та породотвірних, другорядних мінералів, визначили їх кількісні співвідношення у складі відсіву та особливості перерозподілу гематиту і нерудних мінералів по продуктах збагачення.

Результати досліджень і їх аналіз. Результати рудорозбирання показали, що компонентний склад відсіву неоднорідний. Головні компоненти - багаті залізні руди, збагачені та рядові гематитові кварцити, другорядні - різного складу сланці, малорудні та безрудні кварцити, жильний кварц, а також інші гірські породи (граніти, амфіболіти, діабази, доломітові мармури та ін.) (табл. 1). 


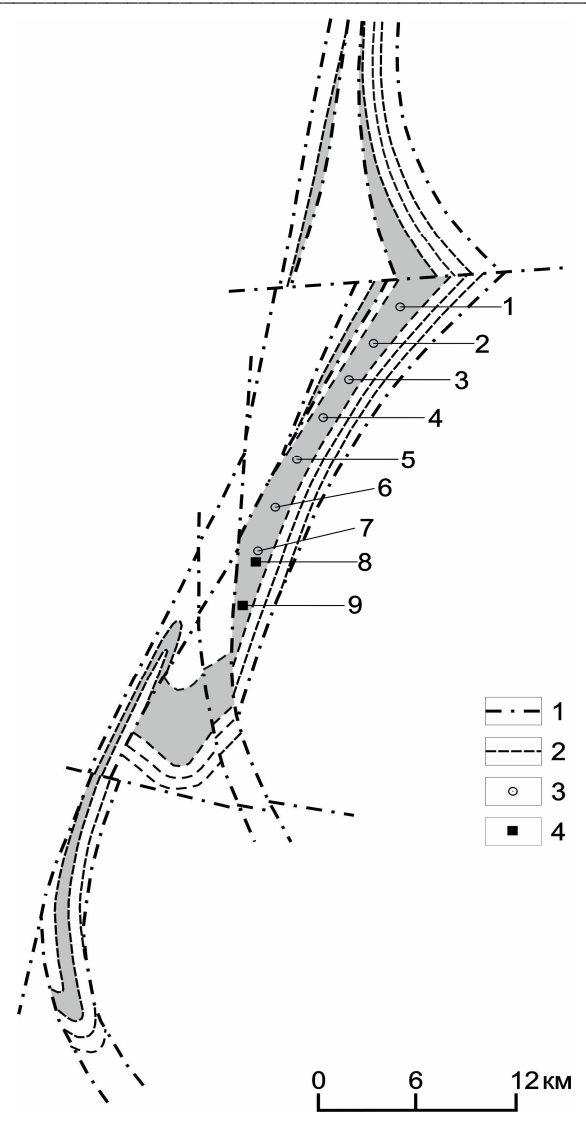

Рис. 1. Положення гірничодобувних підприємств із видобутку багатих гематитових руд Криворізького басейну: 1 - розривні порушення; 2 - лінії стратиграфічних контактів; 3 - родовища, які розробляються підземним способом; 4 - родовища, які розробляються відкритим способом.

Шахти: 1 - Тернівська; 2 - Гвардійська; 3 - Ювілейна; 4 - ім. М. В. Фрунзе; 5 - Зоря-Октябрська; 6 - Родіна; 7 - № 1 ім. Ф. А. Артема.

Кар'єри: 8 - Південний; 9 - Північний

Табл. 1 Кількісні співвідношення мінеральних різновидів руд і гірських порід (мас.\%) у складі крупнозернистого відсіву ДСФ шахт

\begin{tabular}{|c|c|c|c|c|c|c|c|c|c|c|}
\hline № & Родовища & 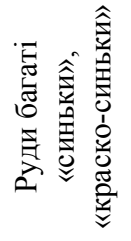 & 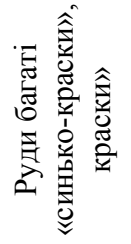 & 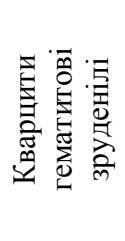 & 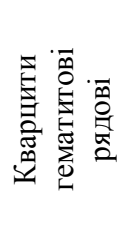 & 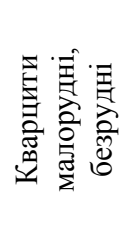 & 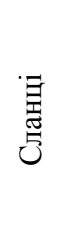 & 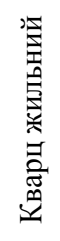 & 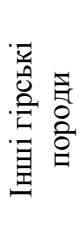 & 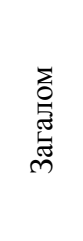 \\
\hline 1 & $\begin{array}{l}\text { кар'єру «Північний» колишнього } \\
\text { iм. Ф. Е. Дзержинського }\end{array}$ & 9,8 & 2,0 & 7,1 & 77,5 & 1,8 & 0,9 & 0,2 & 0,7 & 100,0 \\
\hline 2 & $\begin{array}{l}\text { кар’єру «Південний» шахти } \\
\text { №1 ім. Ф. А. Артема }\end{array}$ & 10,1 & 1,8 & 6,6 & 78,1 & 1,5 & 1,0 & 0,3 & 0,6 & 100,0 \\
\hline 3 & шахти №1 ім. Ф. А. Артема & 9,8 & 1,7 & 6,1 & 79,4 & 1,4 & 0,9 & 0,2 & 0,5 & 100,0 \\
\hline 4 & шахти «Родіна» & 9,6 & 1,5 & 5,9 & 80,2 & 1,3 & 0,9 & 0,2 & 0,4 & 100,0 \\
\hline 5 & шахти «Зоря-Октябрська» & 9,7 & 1,3 & 6,2 & 80,4 & 1,0 & 0,7 & 0,3 & 0,4 & 100,0 \\
\hline 6 & шахти ім. М. В. Фрунзе & 9,5 & 1,2 & 5,6 & 81,4 & 1,1 & 0,8 & 0,1 & 0,3 & 100,0 \\
\hline 7 & шахти «Ювілейна» & 9,3 & 1,3 & 5,7 & 81,7 & 0,9 & 0,6 & 0,2 & 0,3 & 100,0 \\
\hline 8 & шахти «Гвардійська» & 8,6 & 1,1 & 4,9 & 83,2 & 0,9 & 0,6 & 0,3 & 0,4 & 100,0 \\
\hline 9 & шахти «Тернівська» & 7,9 & 0,8 & 5,3 & 84,3 & 0,8 & 0,5 & 0,2 & 0,2 & 100,0 \\
\hline & Середнс значення & $\mathbf{9 , 4}$ & 1,4 & 5,9 & 80,7 & 1,2 & 0,8 & 0,2 & $\mathbf{0 , 4}$ & 100,0 \\
\hline
\end{tabular}

Наведені в таблиці 1 дані свідчать про подібність мінерального складу ДСФ усіх шахт Кривбасу. Головний компонент відсіву - рядові гематитові кварцити із середнім вмістом заліза близько 38 мас.\%. Ці породи є вмісними відносно до покладів багатих залізних руд. Через складність контурів рудних тіл і недосконалість технології видобутку руд гематитові кварцити потрапляють до рудної маси, яка подається на ДСФ. Їх технологічні схеми включають тристадійне дроблення 
та три-чотиристадійне грохочення дробленої маси. До дрібнозернистого продукту грохотіння останньої стадії потрапляють, переважно, частинки багатих гематитових руд, які характеризуються низькою міцністю. Стійкі до механічних навантажень частинки гематитових кварцитів концентруються в крупнозернистому надрешітному продукті всіх стадій грохочення.

Потрапляння до відсіву частинок багатих залізних руд (вміст заліза від 46 до 69 мас.\%, середній показник 63 мас.\%) і збагачених гематитових кварцитів (середній вміст заліза 43 мас.\%) пов'язане з їх потраплянням у процесі дроблення до тіней тиску більш крупних і міцних частинок гематитових кварцитів. Внаслідок цього частинки багатих руд і збагачених гематитових кварцитів виявляються недодробленими і в процесі грохочення потраплять до надрешітного продукту.
Із цим же пов'язана присутність у складі відсіву механічно нестійких частинок сланців.

Частинки малорудних, безрудних кварцитів, жильного кварцу, інших гірських порід характеризуються високою міцністю, внаслідок чого нагромаджуються у відсіві.

Результати мікроскопічних мінералогічних досліджень показали, що матеріал відсіву характеризується практично бімінеральним (гематит + кварц) складом. Загальний вміст гематиту і кварцу в складі відсіву становить близько 97 мас.\%. Кількість другорядних мінералів (реліктовий магнетит, гетит, каолініт) близько 2,5 мас.\%; рідкісних (гідробіотит, стильпномелан, селадоніт, тальк, пірит, марказит, апатит та ін.) до 0,5 мас.\%. За результатами кількісних мінералогчних підрахунків визначено середній мінеральний склад відсіву ДСФ усіх шахт Кривбасу (табл. 2).

Табл. 2 Середній мінеральний склад крупнозернистого відсіву ДСФ шахт Кривбасу

\begin{tabular}{|c|c|c|c|}
\hline \multirow{2}{*}{ Мінерали та мінеральні різновиди } & \multicolumn{3}{|c|}{ Вміст мінералів, мас.\% } \\
\hline & багаті руди & гематитові кварцити & відсів у цілому \\
\hline гематит, & 86,69 & 57,59 & 60,73 \\
\hline в тому числі: - мартит & 73,41 & 48,74 & 51,40 \\
\hline - залізна слюдка & 4,61 & 3,07 & 3,24 \\
\hline - дисперсний гематит & 8,67 & 5,78 & 6,09 \\
\hline магнетит & 1,01 & 0,67 & 0,71 \\
\hline гідроксиди заліза, & 0,17 & 0,11 & 0,12 \\
\hline в тому числі: - гетит & 0,14 & 0,09 & 0,10 \\
\hline -лепідокрокіт & 0,02 & 0,01 & 0,01 \\
\hline - дисперсний гетит & 0,01 & 0,01 & 0,01 \\
\hline мінерали групи кварцу, & 9,90 & 40,15 & 36,90 \\
\hline в тому числі: & 9,67 & 39,59 & 36,47 \\
\hline - квари новоутворений & 0,15 & 0,43 & 0,40 \\
\hline - халцедон & 0,06 & 0,09 & 0,09 \\
\hline- опал & 0,03 & 0,04 & 0,04 \\
\hline силікати, & 1,32 & 0,88 & 0,93 \\
\hline в тому числі: & 0,04 & 0,03 & 0,03 \\
\hline - епігенетичні гіпергенні & 1,28 & 0,85 & 0,90 \\
\hline карбонати, & 0,27 & 0,18 & 0,19 \\
\hline в тому числі: & 0,06 & 0,04 & 0,04 \\
\hline - епігенетичні гіпергенні & 0,21 & 0,14 & 0,15 \\
\hline сульфіди, & 0,06 & 0,04 & 0,04 \\
\hline в тому числі: & 0,04 & 0,03 & 0,03 \\
\hline -марказит & 0,01 & 0,01 & 0,01 \\
\hline -мельниковіт & 0,01 & 0,01 & 0,01 \\
\hline галогеніди (галіт, сильвін) & 0,40 & 0,27 & 0,28 \\
\hline сульфати (гіпс, алуніт, барит, & 0,05 & 0,03 & 0,03 \\
\hline Апатит & 0,11 & 0,07 & 0,07 \\
\hline акцесорні минералі (циркон, & 0,01 & 0,01 & 0,01 \\
\hline Всього & 100,00 & $\mathbf{1 0 0 , 0 0}$ & 100,00 \\
\hline
\end{tabular}


3 метою розроблення мінералогічного обгрунтування оптимальної технологічної схеми повторного збагачення відсіву автори детально дослідили мінералогічні особливості головного рудотвірного мінералу відсіву - гематиту.

Гематит - характеризується середнім вмістом у складі відсіву 60,73 мас.\%. Він представлений трьома морфологічними різновидами: залізною слюдкою (3,24 мас.\%), мартитом (51,40 мас.\%) та дисперсним гематитом (6,09 мас.\%).

Залізна слюдка присутня у вигляді двох генерацій (рис. 2, 3): метаморфогенної (залізна слюдка 1) та гіпергенної (залізна слюдка 2). Метаморфогенна залізна слюдка утворює дві відміни: «емульсійний» гематит нерудних прошарків гематитових кварцитів, який представлений дрібними (від 0,001 до 0,05 мм) пойкілобластами в агрегатах кварцу; друга відміна метаморфогенного гематиту - спекулярит у складі альпійських жил кварцу, розмір його кристалів досягає 20 мм за максимальним виміром. Гіпергенна залізна слюдка утворює ланцетоподібні кристали, які наростали на агрегатах мартиту («їжакові» структури (рис. 4)) у зв'язку з локальною міграцією заліза під час мартитизації магнетиту в процесі вивітрювання залізистих кварцитів та багатих руд (Kanibolotsky 1946; Belevtsev, Bura 1959; Belevtsev, Tokhtuev, e.a. 1962; ).

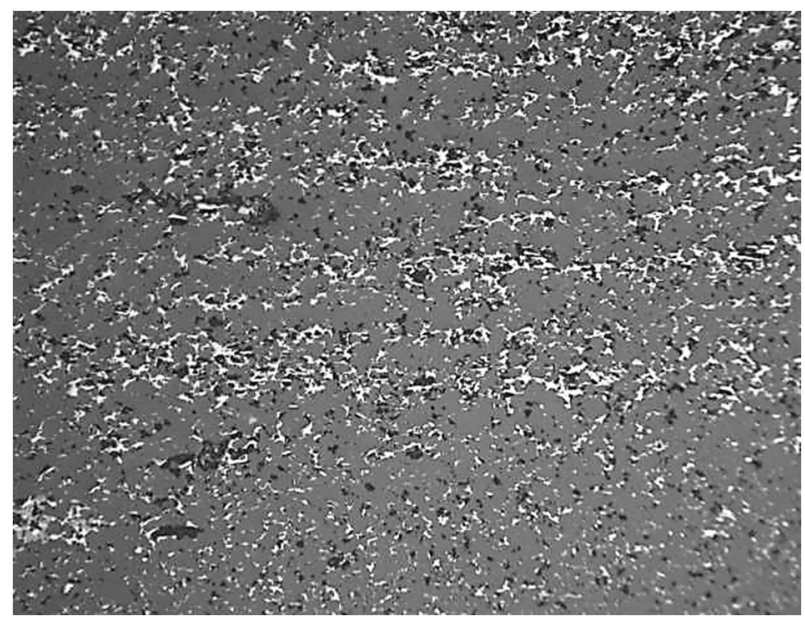

$a$

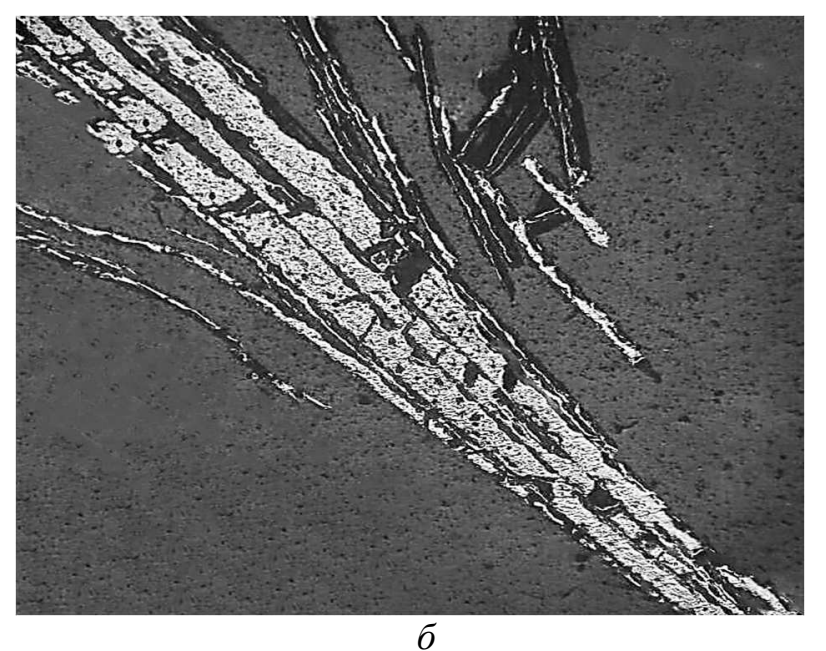

Рис. 2. Морфологічні різновиди залізної слюдки в складі руд і гематитових кварцитів з відсіву ДСФ: емульсійна залізна слюдка (а); спекулярит (б).

Біле - залізна слюдка; темносіре - кварц; чорне - пори.

Відбите світло; без аналізатора; збільшення $30^{x}$

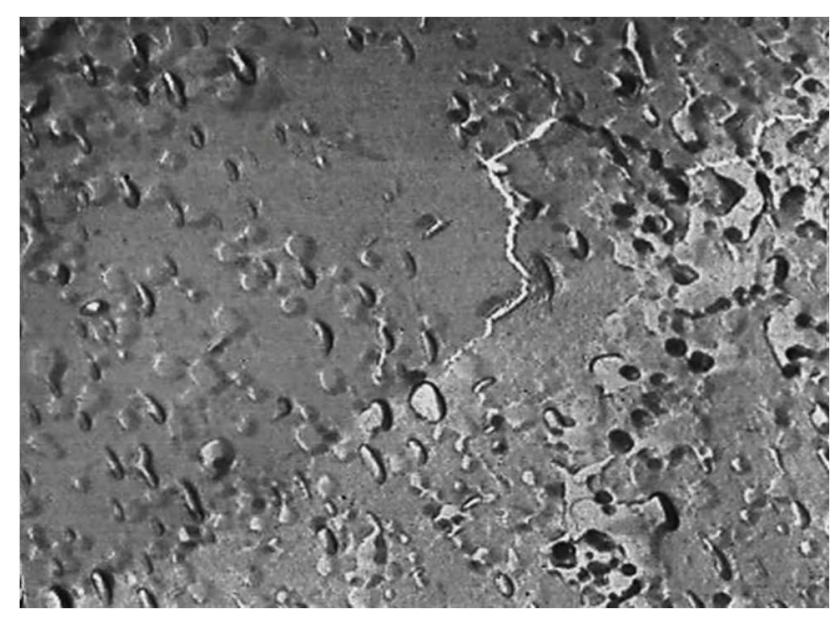

$a$

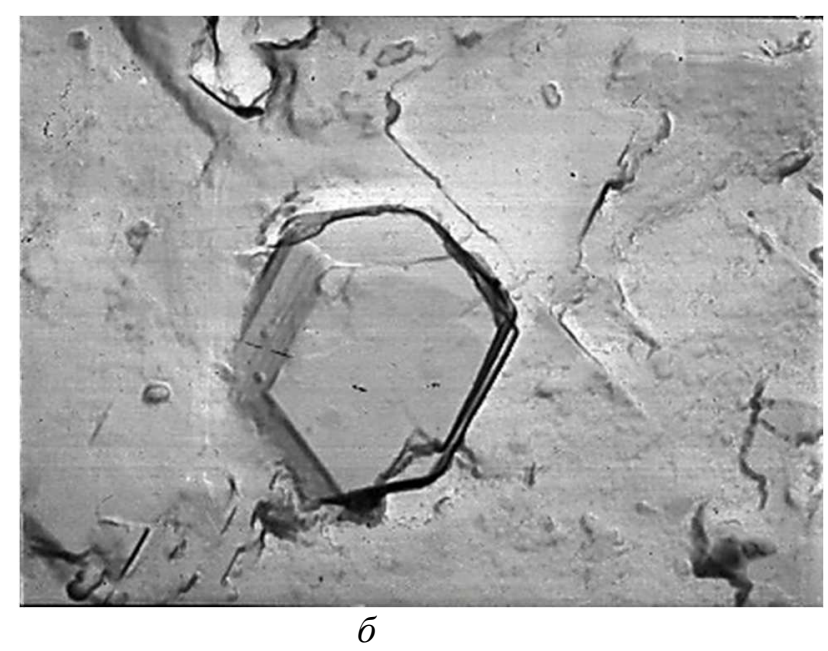

$\sigma$

Рис. 3. Морфологія індивідів залізної слюдки в нерудному прошарку залізнослюдко-мартитового кварциту (а) та в альпійському залізнослюдко-кварцовому прожилку в мартитовому кварциті (б) з відсіву ДСФ родовища шахти ім. М. В. Фрунзе. Растровий електронний мікроскоп МРЕМ-100, збільшення $600^{x}$ 

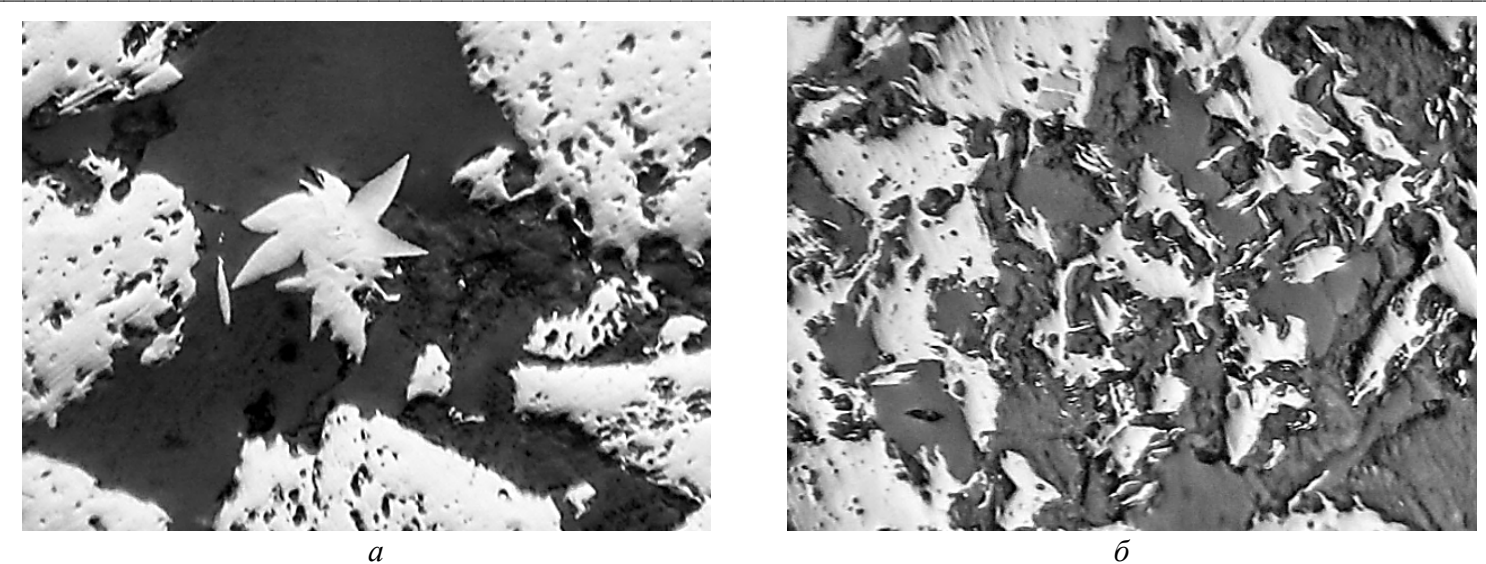

Рис. 4. Їжакоподібні агрегати ромбоедричних кристалів гіпергенної залізної слюдки, які наросли на субізометричних агрегатах мартиту.

Біле - мартит, залізна слюдка; темносіре - кварц; чорне - пори.

Відбите світло; без аналізатора; збільшення $100^{\mathrm{x}}$

У процесі рудопідготовки (дроблення, подрібнення) та виконання попередніх мінералоготехнологічних експериментів спостерігався чіткий перерозподіл залізної слюдки різних морфологічних відмін по різних одержуваних продуктах. Емульсійний гематит нерудних прошарків гематитових кварцитів через незначний розмір виділень у процесі подрібнення не розкривається і в підготовленому до збагачення матеріалі присутній у вигляді включень в частинках кварцу. Під час гравітаційного або магнітного збагачення потрапляє, головним чином, до хвостів. Спекулярит ефективно дробиться та подрібнюється, в підготовлених до збагачення продуктах представлений мономінеральними частинками, і в процесі збагачення практично повністю потрапляє до концентрату. Гіпергенна залізна слюдка утворює спільні агрегати 3 мартитом. Під час подрібнення разом із ним ефективно розкривається, в підготовлених до збагачення продуктах присутня у вигляді мономінеральних агрегатів гематиту. Технологічний негатив «їжакового» гематиту - недостатня міцність, через що він, як і мартит, схильний до переподрібнення 3 утворенням частинок розміром менше 0,02 мм. У разі застосування стандартних

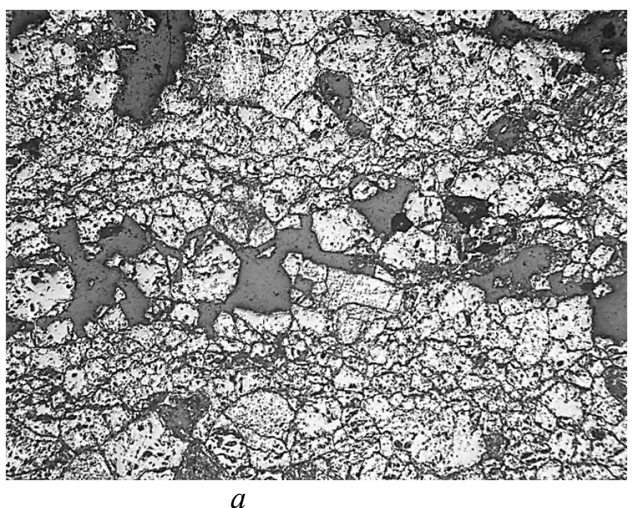

методів збагачення (магнітні, гравітаційні) частинки такого розміру переважно втрачаються у відходах.

Mapmum - головний рудний мінерал відсву - являє собою продукт вивітрювання первинного магнетиту (Gershoyg 1955; Martynenko 1955, Akimenko, Belevtsev1957). В частинках багатих руд і в рудних прошарках частинок гематитових кварцитів утворює псевдоморфози по виділеннях магнетиту, внаслідок чого його агрегати успадковують форми його індивідів і агрегатів - стрічкоподібні, блокові, гілчасті, вкраплені (рис. 5). Розмір виділень мартиту відповідає розміру кристалів первинного магнетиту, коливається переважно від 0,01 до 0,15 мм, середні показники 0,050,07 мм. Псевдоморфози являють собою тонкопористий агрегат, складений дуже дрібними (зазвичай менше 0,1 мм за максимальним виміром) лускуватими, ланцетоподібними кристалами залізної слюдки (рис. 6). Зрідка мартит присутній у нерудних прошарках збагачених і рядових гематитових кварцитів. Від мартиту рудних прошарків він відрізняється меншим розміром агрегатів - від 0,005 до 0,05 мм, в середньому близько 0,02 мм.

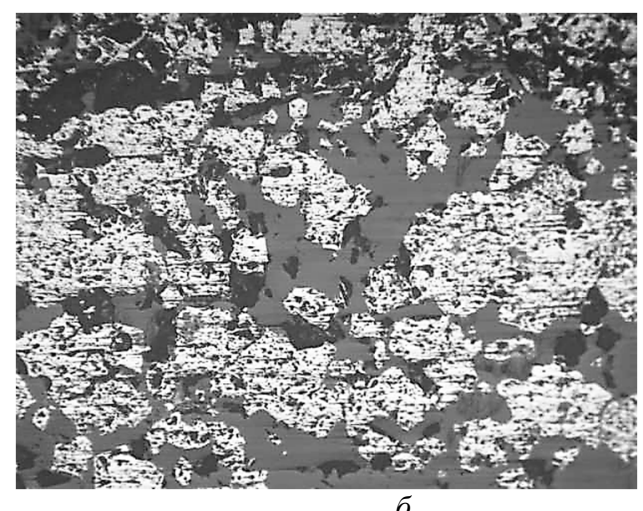

6

Рис. 5. Особливості морфології агрегатів мартиту з частинок багатої мартитової руди (а) і рудного прошарку мартитового кварциту (б) з відсіву ДСФ родовища шахти Ювілейна.

Світлосіре - мартит; темносіре - кварц; чорне - пори.

Відбите світло; без аналізатора; збільшення $30^{x}$ 

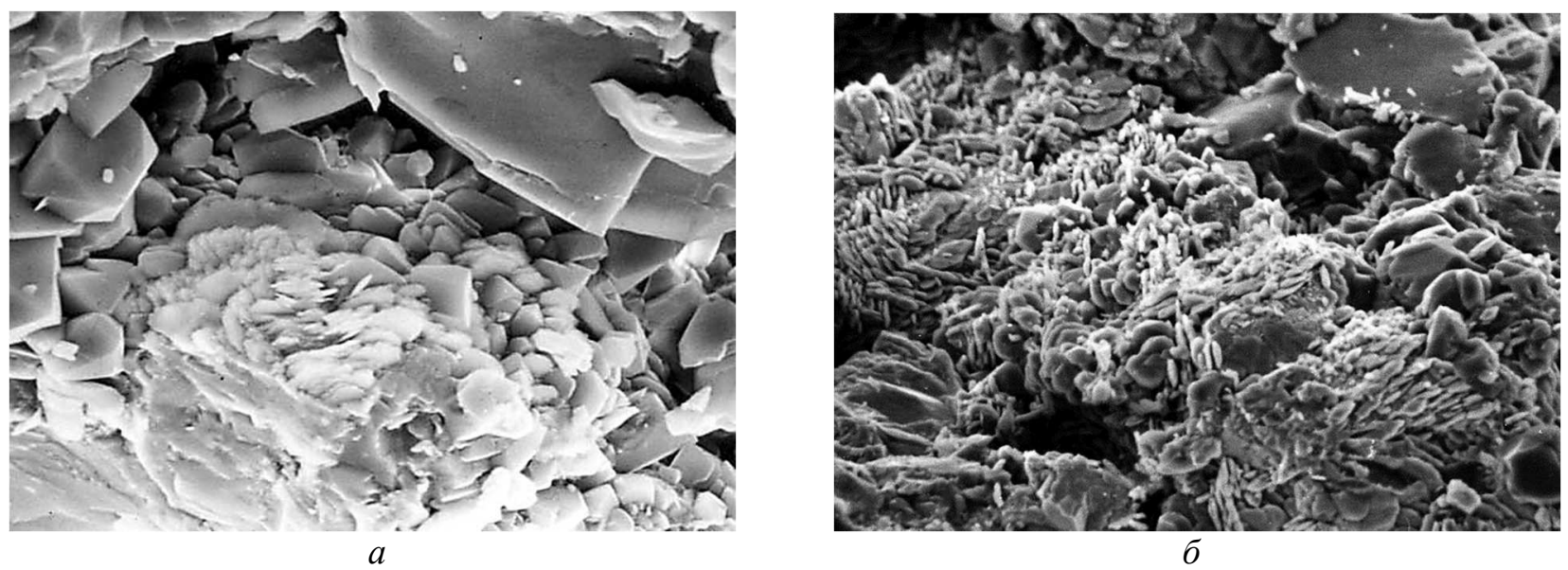

Рис. 6. Тонколускувата будова агрегатів мартиту (Smirnov 2014).

Растровий електронний мікроскоп МРЕМ-100. Збільшення: $a-1500^{\mathrm{x}}, \sigma-800^{\mathrm{x}}$

Тонкопориста будова агрегатів мартиту, як зазначалось вище, зумовлює їх більш низьку механічну стійкість порівняно з головним нерудним мінералом - кварцом. Тому під час підготовки рудного матеріалу до збагачення, яка полягає в дробленні і подрібненні матеріалу відсіву, виділення мартиту проявляють схильність до переподрібнення. Через це для розроблення оптимальної технологічної схеми виробництва гематитового концентрату необхідно запровадити щадні методи подрібнення під час рудопідготовки, а також постадійне виведення матеріалу необхідного гранулометричного складу із циклу подрібнення до готового рудного потоку, який направляється на збагачення.

У досліджених авторами продуктах рудопідготовки матеріалу семи об'єднаних проб відсіву та продуктах їх гравітаційного збагачення крупність частинок становила $-0,1+0$ мм. Мартит у цих продуктах характеризувався розміром частинок від менше 0,01 до 0,07 мм, кварц - від менше 0,01 до 1,0 мм. Мікроскопічні підрахунки продуктів подрібнення показали, що 83,3 \% від загальної кількості частинок мартиту були мономінеральними, 16,7 \% частинок були представлені зростками $з$ різним кількісним співвідношенням мартиту і кварцу. В продуктах гравітаційного збагачення подрібненого матеріалу це співвідношення значно зросло на користь мономінеральних частинок мартиту: кількість мономінеральних частинок становила 95,1 \% від їх загальної кількості, зростків - 4,9\%; зростки були представлені переважно багатими з умістом мартиту понад $75 \%$ та кварцу, відповідно, менше $25 \%$. Розмір частинок мартиту в концентраті становив від 0,02 до 0,07 мм. Частинки розміром менше 0,02 мм через їх недостатньо активну участь у гравітаційному розділенні у зв'язку з незначною масою потрапили разом із мономінеральними частинками кварцу i бідними зростками до відходів збагачення.

Дисперсний (пилоподібний) гематит міститься у складі відсіву в кількості близько 6 мас.\%. Присутній, головним чином, у частинках каолініт-дисперсногематитової, дисперсногематитової («краска») та мартит-дисперсногематитової («синько-краска») руди та малорудних залізистих кварцитів. За даними попередніх дослідників, утворення дисперсного гематиту - результат вивітрювання залізовмісних силікатів, карбонатів, сульфідів, причому в разі присутності в складі силікатів глинозему одночасно $з$ дисперсним гематитом утворювався глинистий мінерал (Kanibolotsky 1946; Belevtsev, Bura 1959; Evtekhov1997). Автори цієї статті методом рентгеноструктурного аналізу встановили, що в складі відсіву всіх ДСФ глинистий мінерал представлений каолінітом (рис. 7). 


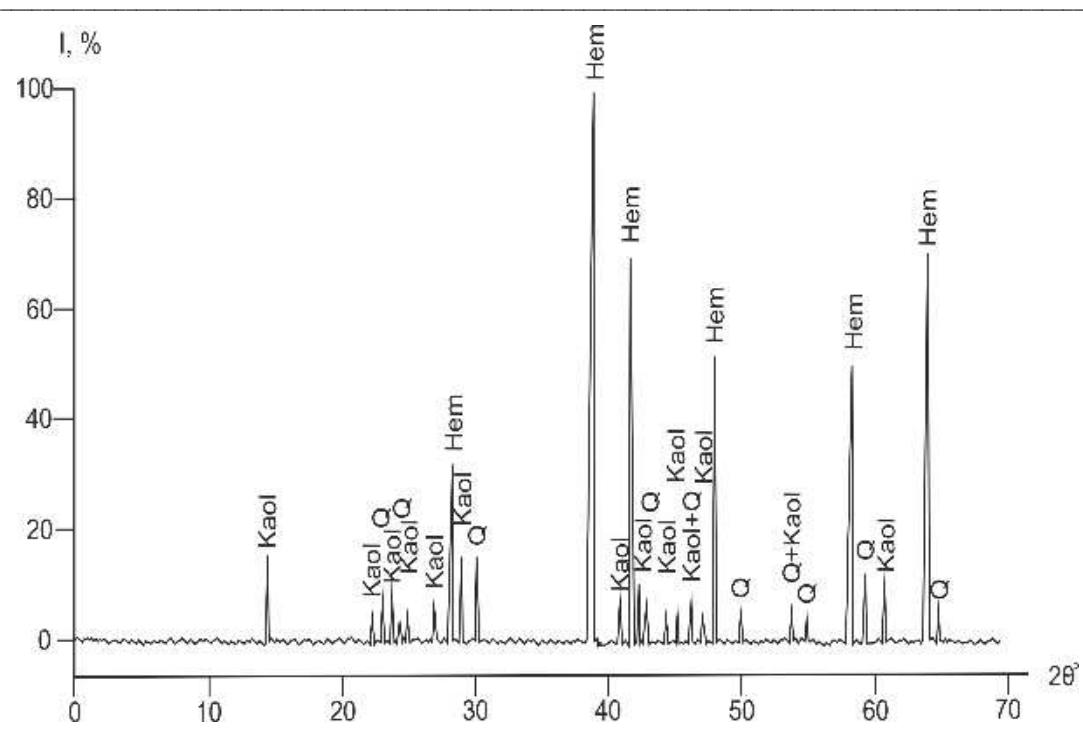

Рис. 7. Рентегенограма каолініт-кварц-дисперсногематитової складової матеріалу відсіву. Kaol - каолініт; Q - кварц; Нет - гематит

Розмір пластинчастих індивідів дисперсного гематиту, а також каолініту зазвичай не перевищує 0,001 мм. Внаслідок цього, а також через низьку механічну стійкість агрегатів цих мінералів під час рудопідготовки частинки обох потрапляють до найбільш дрібнозернистих продуктів подрібнення з розміром частинок менше 0,02 мм. У процесі гравітаційного розділення вони потрапляють до відходів збагачення.

Аналіз результатів мінералогічних досліджень і технологічних експериментів показав, що в процесі рудопідготовки (дроблення, подрібнення) і збагачення матеріалу відсіву відбувається перерозподіл гематиту по утворюваних продуктах. На думку авторів, можна виділити три напрямки перерозподілу гематиту:

- концентрація практично всього дисперсного гематиту, а також частини мартиту, який зазнав переподрібнення - в складі найбільш дрібнозернистого продукту подрібнення відсіву (розмір частинок менше 0,02 мм); цей матеріал практично повністю надходить до відходів збагачення;

- утворення рудно-нерудних зростків гематиту та кварцу, до складу яких потрапляє емульсійна залізна слюдка нерудних прошарків рядових гематитових кварцитів і частково - мартит нерудних прошарків; багаті гематитом зростки (вміст рудної складової понад 75\%) потрапляють до концентрату, зростки з більш низьким вмістом гематиту - до відходів збагачення;

- утворення мономінеральних частинок мартиту та крупнозернистої залізної слюдки - основна складова продуктів рудопідготовки, яка надходить до концентрату.

Висновки. 1. Крупнозернистий відсів дробильносортувальних фабрик характеризується розміром частинок від 20 до 100 мм та середнім умістом заліза близько 43 мас.\%. Наразі він досліджується як сировина для виробництва високоякісного (6769 мас.\% заліза) гематитового концентрату. Для розроблення ефективної технології виробництва концентрату необхідне детальне дослідження петрографічного, мінерального, хімічного складу, структури, текстури руд і гірських порід, які входять до складу відсіву.

2. За результатами петрографічних досліджень, відсів складається головним чином із частинок рядових гематитових кварцитів із середнім вмістом заліза близько 38 мас.\%. Другорядні компоненти - багаті залізні руди (63 мас.\%), збагачені гематитові кварцити (43 мас.\%) та малорудні, безрудні гірські породи (менше 25 мас.\%).

3. Мінеральний склад відсіву двокомпонентний - гематит+кварц з незначною домішкою каолініту, беззалізистих карбонатів, гіпергенних сульфідів, реліктових силікатів. Головний рудний мінерал - гематит - представлений трьома морфологічними різновидами: мартитом, залізною слюдкою та дисперсним гематитом.

4. За результатами мінералогічних досліджень, гематит виділених морфологічних різновидів перерозподіляється по продуктах рудопідготовки (дроблення, подрібнення) і збагачення відсіву. Більша частина мартиту та залізна слюдка ефективно розкриваються у процесі рудопідготовки і надходять до концентрату. Переподрібнений мартит і дисперсний гематит через малий розмір частинок (менше 0,02 мм) потрапляють до відходів збагачення. Перерозподіляються також зростки гематиту і кварцу. Багаті зростки з умістом гематиту понад 75 \% залучаються до концентрату, бідні - 3 меншим вмістом гематиту - втрачаються у відходах збагачення. 
5. Особливості перерозподілу гематиту слід враховувати для розроблення оптимальних технологічних схем рудопідготовки і збагачення гематитової сировини.

\section{Бібліографічні посилання}

Akimenko, N.M., Belevtsev, Ya.N., Goroshnikov, B.I., Dubinkina, R.P., Ishchenko, D.I., Karshenbaum, A.P., Kulishov, M.P., Lyashchenko, K.P., Maksimovich, V.L., Skuridin, S.A., Siroshtan, R.I., Tokhtuev, G.V., Fomenko, V.Yu., Shcherbakova, K.F. (1957), Geologicheskaja struktura i zheleznye rudy Krivorozhskogo bassejna [Geological structure and iron ores of the Krivoy Rog basin], Gosgeoltekhizdat press, Moscow, 280 (in Russian).

Belevtsev, Ya.N., Bura, G.G., Dubinkina, R.P., Yepatko, Yu.M., Ishchenko, D.I., Melnik, Yu.P., Strygin, A.I. (1959), Genezis zheleznyh rud Krivorozhskogo bassejna [Genesis of iron ores of the Krivoy Rog basin], Publ. house of Acad. of Sci. of the UkrSSR, Kyiv, 360. (in Russian).

Belevtsev, Ya.N., Kravchenko, V.M., Kulik, D.A., Belevtsev, R.Ya., Borisenko, V.G., Drozdovskaya, A.A., Yepatko, Yu.M., Zankevich, B.A., Kalinichenko, O.A., Koval', V.B., Korzhnev, M.N., Kusheev, V.V., Lazurenko, V.I., Litvinskaya, M.A., Nikolaenko, V.I., Pirogov, B.I., Prozhogin, L.G., Pikovskiy, Ye.Sh., Samsonov, V.A., Skvortsov, V.V., Savchenko, L.T., Stebnovskaya, Yu.M., Tereshchenko, S.I., Chaykin, S.I., and Yaroshchuk, M.A. (1991), Zhelezisto-kremnistye formacii dokembrija evropejskoj chasti SSSR [Banded iron Precambrian formations of the European part of the USSR]. Genesis of iron ores, Nauk. dumka, Kyiv, 216 (in Russian).

Belevtsev, Ya.N., Tokhtuev, G.V., Strygin, A.I., Melnik, Yu.P., Kalyaev, G.I., Fomenko, V.Yu., Zagoruyko, L.G., Molyavko, G.I., Polovko, N.I., Dovgan, M.N., Ladieva, V.D., Zhukov, G.V., Epatko,
Yu.M., Shcherbakov, B.D. (1962), Geologija Krivorozhskih zhelezorudnyh mestorozhdenij [Geology of Kryvyi Rih iron ore deposits], Publ. house of Acad. of Sci. of the UkrSSR, Kyiv, UA, Vol. 1, 484 p. and Vol. 2, (in Russian).

Demchenko O.S., Evtekhov V.D. (2015) Petrografichnyi sklad vidsivu drobarno-sortuvalnyh fabryk Krivorizkogo baseinu [Petrographic composition of screenings from crushing and screening plants of the Kryvyi Rih basin] Sustainable development of industry and society. Section 5. Geology, applied mineralogy. Ecology. International scientific-technical conference proceedings. Kryvyi Rih: Kryvyi Rih national university, 62-66 (in Ukrainian).

Evtekhov, V.D. (1997), Etapi formuvannja kompleksnoï mineral'no-sirovinnoï bazi zalizorudnih rodovishh Krivoriz'ko-Kremenchuc'kogo lineamentu [Stages of formation of a complex mineral-raw material base of iron ore deposits of the Krivoy Rog-Kremenchug lineament]. Data of the Acad. of Mining Sci. of Ukraine, No. 4, 111-114 (in Ukrainian).

Gershoyg, Yu.G. (1955), Genezis rud Krivogo Roga [Genesis of the Krivoy Rog iron ore basin], Publ. house of Acad. of Sci. of the UkrSSR, Kyiv, 86-99 (in Russian).

Kanibolotsky, P.M. (1946), Petrogenezis porod i rud Krivorozhskogo zhelezorudnogo bassejna [Petrogenesis of rocks and ores of Krivoy Rog iron ore basin], Publ. house of Acad. of Sci. of the UkrSSR, Chernovtsy, 312 (in Russian).

Martynenko, L.I. (1955), Rol' gipergennyh processov v obrazovanii rud Saksaganskoj polosy Krivogo Roga [Geology and genesis of ores of the Krivoy Rog iron ore basin], Publ. Acad. of Sci. of UkrSSR, Kyiv, 100-113 (in Russian).

Smirnov O.Ya. (2014) Geology of low grade hematite ore deposits (hematite quartzites) of Valiavkinske deposit in Kryvyi Rih basin. Manuscript (in Russian). 